CONJUNTURA AUSTRAL

journal of the global south

\title{
NATO AND THE SOUTH ATLANTIC
}

\section{A OTAN e o Atlântico Sul}

\author{
Carlos Gustavo Poggio Teixeira ${ }^{1}$ \\ Daniella da Silva Nogueira de Melo ${ }^{2}$
}

\section{Introduction}

In May 2018, Colombia was recognised as a NATO global partner, being the first Latin American country to formalize this relationship. The historical and political context of the South Atlantic differs from the reality of central and eastern Europe and the Middle East where the organization has mainly acted. In the last decades, NATO presence in the South Atlantic has received a little academic discussion. This is not due to lack of evidence, as the formation of partnerships with Colombia, Mauritania, joint military operations with Cape Verde, Ghana and other countries of the western African coast reveal the importance that the South Atlantic has acquired for the Alliance's agenda and its members. This article intends to contribute to this gap in the literature.

In the 1970s, the South Atlantic was involved in the organization's security agenda. The Soviet presence in obstructing Maritime Communication Lines (MCL) and the trading of oil and other raw materials started worrying the Western powers. However, without formalizing a specific policy on out-ofarea operations, NATO performance in the region was restricted (COAKER, 1985; CURREN, 1988; VIEGAS FILHO, 2016).

After the Cold War, the Alliance experienced a process of expanding its spatial and functional scope, incorporating aspects of a collective security organization (ORFY, 2011). Following the Realist school, we can interpret the NATO preservation as a result of the members' intention to continue making it viable to their foreign policy goals. Institutions such as NATO reflect the calculation of the most powerful states'

${ }^{1} \mathrm{PhD}$ em International Studies pela Old Dominion University (Virgínia, EUA) com título de doutor reconhecido no Brasil pela Universidade de São Paulo (USP). Conduziu pesquisa de pós-doutorado na Georgetown University (Washington DC, EUA). Professor do Programa de Pós Graduação San Tiago Dantas (UNESP, UNICAMP, PUC-SP), e do curso de Relações Internacionais da FAAP. Coordenador do Núcleo de Estudos sobre a Política Externa dos Estados Unidos (NEPEU). Email: cgpteixeira@gmail.com

${ }^{2}$ Doutoranda em Ciência Política e Relações Internacionais na Universidade do Minho, Braga (Portugal). Possui Mestrado pelo Programa Pós-graduação em Relações Internacionais San Tiago Dantas (UNESP, UNICAMP e PUC-SP). Email: dani_melo192@hotmail.com 
interests in securing their power positions in the world. As neorealist author once put it "[...] the recent history of NATO illustrates the subordination of international institutions to national purposes" (WALTZ, 2000, p.18). The realist theoretical framework will support the analysis of how NATO has served both the US and some European allies' agenda (Great Britain, Portugal, France, Spain) in reaffirming their power's position in the South Atlantic.

In the current scenario, the South Atlantic has gradually become the strategic stage for designing NATO forces. Bearing in mind the members' interests (USA, Great Britain, France, Portugal, Spain) the regional powers' perspective (Brazil and Argentina) and the operational area exogenous to its constitutional treaty, this article intends to answer the following research question: "What has led NATO to become involved in the current geopolitical conjuncture in the South Atlantic?”. In order to do so, we will analyse the following variables: the abundance of natural resources, threats to regional security, and the presence of extraregional countries such as China, Russia and India. This article aims to describe the magnitude of NATO involvement in the South Atlantic since the Cold War considering the transformation of the organization and the interests of its most powerful members. Our hypothesis is that the combination of these three variables is essential in explaining NATO's increasing interest in the South Atlantic.

\section{Out-of-area operations during the Cold War}

The called "Third World" during the Cold War was considered as a "secondary theater of operations" (COKER, 1985, p.11) and could serve only as strategic supply bases for NATO. Areas such as the Mediterranean, Middle East, South Atlantic and Indian Ocean constituted trade routes, markets and sources of raw materials (BARTOLOMÉ, 2012). However, there wasn't policy formulation specific to out-of-area operations, although NATO Secretary General Brosio in 1965 had held meetings to that goal. This context is related to the hierarchy of norms within the framework of the organization's responsibilities. Out-of-area issues were subordinated to the collective defence principle (Article 5). Economic problems or those associated with colonies wouldn't result in a collective response and could be dealt with by ad hoc arrangements, outside the formal scope of the Alliance (KITCHEN, 2010).

This hierarchy prevented the internal cohesion from being undermined as well as the evolution of marginal conflicts into a global scale. There were divergences of interest, of threat perceptions between members, and budget constraints. From the US perspective, the Caribbean Basin and South Atlantic meant more to their own hemispheric security than from the European perspective. While the UK, USA and France began advocating global interventionist measures, Iceland, Denmark, Greece, Canada, Turkey, Norway, West Germany, Italy, Belgium preferred NATO to maintain its regional scope. The latter group feared that an expanded range of action would provoke hostilities with the USSR and divert NATO resources for purposes other than European security (COKER, 1985; HURRELL, 1988). 


\section{The South Atlantic on the NATO agenda during the Cold War}

The fact that no military operation under NATO command was implemented in the South Atlantic in the Cold War did not mean that the region was excluded from the organization's agenda. In the 1950s, the USSR strategy was to invest in naval warfare to push for the control of the seas and to neutralize the exclusivity of the western powers (BARTOLOME, 2012). In 1969, soviets already had a ship on the African coast. The South Atlantic was an alternative way of trading commodities crucial to the industries in the Northern Hemisphere (HURRELL, 1988). The transportation costs for oil barrels through the Cape of Good Hope was more advantageous than through the Suez Canal. The importance of the Cape route became more evident when the Suez Canal was closed by Egypt in 1967 (PENHA, 2011, BARTHOLOMEW, 2012). By fomenting a 'resources war' through the obstruction of the MCLs, the Soviet strategic was to weaken the Western economies, control sources of raw material supply and cause instabilities without directly attacking territories (VIEGAS FILHO, 2016).

In the face of an unlikely direct aggression between the USA and the USSR due to nuclear deterrence, their tensions were transferred to the Third World. Cuba, as a Soviet ally, was a US concern since it was in its 'backyard' and could serve as a military and logistical base for the USSR. Americans also feared the Panama Canal could be obstructed (VIEGAS FILHO, 2016). With independence processes in Africa, the Soviets supported national liberation movements of domestic groups and gained access to the ports of Angola, Mozambique, Guinea Bissau, Benin, Cape Verde, Tanzania, Congo and Cameroon. In 1970, after the USSR dispatched a navy squadron in response to Portugal's resistance in Conakry (Guinea), they developed a sophisticated South Atlantic surveillance system. Their aim was to control the Cuba-Guinea axis and to isolate South Africa by obstructing maritime trade. The USSR had bases near Antarctica on the May 25 island and along the Cape Route (PENHA, 2011).

The South Atlantic was firstly discussed within NATO based on these developments (HURRELL, 1988). Portugal, Belgium and France supported a military project for a permanent naval force in the south, along the lines of the organization's 1968 Standing Naval Force Atlantic. In the 1980s, it was considered to create a defence mechanism, highlighting the value of the Malvinas Islands as a strategic base. NATO Secretary-General Joseph Luns expressed an interest in including the South Atlantic in the collective defence pact. At the Royal United Services Institute for Defence and Security Studies, it was considered to expand NATO defence responsibilities to other locations and to delegate an enforcement role to the UK (COKER, 1985).

In the 1970s, there was also a proposal to implement an integrated defence mechanism by the southern countries' initiative. The South Atlantic Treaty Organization (SATO) would assume a format similar to NATO model. It was strongly supported by the Argentines who feared Brazilian power projection, and by the South Africans, who sought to attract allies in order to avoid political isolation. Brazil did not maintain a supportive position for the pact, fearing the militarization of the South Atlantic and did not see the Soviet threat so alarming. In addition, SATO's infeasibility was also due to the USA and Great Britain cautious positioning over the military projections of the southern countries (HURRELL, 1983). 
In 1981, the Alliance was involved in the South Atlantic contingency plan in conjunction with Latin American navies, known as Ocean Venture 81. The operation aimed to keep safe routes in the North and South Atlantic and the Baltic, including NATO members, Argentina, Brazil, Colombia, Uruguay, Venezuela, Chile, South Africa. Although this activity occurred outside the NATO official command, five areas were monitored, reinforcing the interoperability among the navies (HURRELL, 1988; PENHA, 2011).

NATO also marked its presence through initial support for the South African surveillance centres. The communications base at Silvermine gathered information from Soviet ships and submarines with the intention of intercepting commercial shipping at the Cape of Good Hope (PENHA, 2011). According to Coker (1985), even if data exchange existed between NATO and Silvermine, there wasn't direct contact between the intelligence authorities. In times of war, each country would provide offices to accommodate members' navy officers. In 1976, unconfirmed speculations involved a secret agreement between South Africa's prime minister, NATO commander and Henry Kissinger. The agreement, though denied by Luns, included military arsenal and articulation between the Alliance and South African Defence (COKER, 1985).

\section{A Trajectory of Transformations}

After the Cold War, NATO experienced a transformation period on operational and institutional capacities to adapt to the new security scenario. Realist theory seems to provide some guidelines to explain the NATO preservation and its new role. In the 1990s, through the Alliance, the USA understood that could continue to extend its control over European affairs and prevent security competition conflicts from emerging in Europe (WALTZ, 2000). Moreover, the organization was strategically oriented to spread Western liberal values and norms to the post-Soviet states, consolidating a 'security community' within these standards (MEARSHEIMER, 2017). Alliance would help redefine a 'new world order' as explicitly articulated in the US strategy. Therefore, NATO agenda is subordinated to the promotion of the national interests of its most powerful members. This is in line with the argument made by realists that institutions do not have autonomy nor independent effect on the states' behaviour (WALTZ, 2000).

Political, social and economic instabilities in the Balkans have led NATO to incorporate crisis management and prevention tasks. The use of the organization in interferences outside the Euro-Atlantic sphere serves as a mechanism for gaining legitimacy to US operations (SIRECI; COLETTA, 2009) - "Since its establishment in 1949 the alliance has served the fundamental U.S. interest: it has provided a multilateral framework for the legitimisation and exercise of American influence and power" (RATTI, 2006, p.98). For the Europeans, preserving NATO guarantees an equipped military and nuclear structure to defend their territories and military power projection capability.

The post-9/11 was a milestone in building NATO global role (KITCHEN, 2010). The organization ventured out of Europe in charge of ISAF in Afghanistan, it expanded partnerships and contacts with many regions of the world (Asia, Caucasus, Middle East, South Atlantic), imposing a security structure close to western standards. The encouragement of NATO political dialogue with the world serves the self-interested goals of the US global strategy and the part of European allies in gaining local strategic resources, political 
influence and sharing security costs and responsibilities-"NATO expansion has provided the USA with the opportunity to obtain geographical assets useful for the projection of its influence" as quoted by Ratti (2006, p.99).

These functional changes of the Alliance are portrayed by the strategic concepts, which are documents that expose the military and political guidelines and update threats included in the organization's scope of action. The last two concepts (1999 and 2010) have brought new approaches to outof-area issues. Military activities outside the geographical boundaries of the North Atlantic were formally authorized, with members having to consider case-by-case before deciding to intervene in the conflict. Thus, NATO has control over out-of-area operations and discretionary power to decide whether to get involved in regional crises. Political and military resources and the use of force by NATO are detached from the unique function of self-defence; without the need for direct aggression to member territories (GARCÍA RAMÍREZ, 2014).

According to the Lisbon Strategic Concept (2010) “Crises and conflicts beyond NATO’s borders can pose a direct threat to the security of Alliance territory and populations. NATO will engage, where possible and when necessary, to prevent crises, manage crises, stabilize post-conflict situations and support reconstruction." (NATO, 2010). The criticism of this text's interpretation is that NATO's freedom of action can serve as a justification for acting on the political and economic interests of its members rather than on the goal of world stability (RINGSMOSE; RYNNING, 2011).

Security challenges such as terrorism, cyber-attacks, transnational crimes, natural disasters, political, economic and social instabilities, proliferation of weapons of mass destruction (WMD) and other threats linked to energy, maritime and biodefense security were included in the NATO missions and became known as non-Article 5 (RINGSMOSE, RYNNING, 2011). There is a relationship of interdependence between the objectives of collective defence and non-Article 5 missions. Even though asymmetric threats and regional crises do not mean a direct aggression to the territories, members justify that they can indirectly evolve and pose risks to their securities. There has been a "deterritorialization of the alliance's collective defence mission" (Yost, 2010, p.490). The organization, once limited to the 'static, reactive and territorial' nature brought by Article 5, assumes a flexible and multifaceted attitude to the dynamics of action. NATO takes on global responsibilities and transforms itself in a collective security organization (ORFY, 2011).

\section{Main Engagement Factors}

This session identifies factors that may explain NATO engagement in the South Atlantic. The first element refers to the search for energy security, a pressing issue in the national agendas. The South Atlantic incorporates strategic value because of natural resources. The expected growth of African oil production by 2030 is 153\% while in South America is 144\% (ATLANTICO, 2017).

In the Gulf of Guinea is estimated 86\% of the total proven oil reserves in the continent (ECHENDU; ILEDARE, 2015). The crude oil extracted from this region is lighter and of a higher quality than that of Latin America. Oil production in the Gulf of Guinea is expected to surpass that of the Persian Gulf by 2020. 
Nigeria is the country with the largest reserves. Between 2005 and 2015, European imports from that country increased by 2.7 times (EUROSTAT, 2017). Therefore, "Africa is now looked upon as a key source for major oil importers seeking to diversify imports in order to achieve greater energy security" (AFDB, 2009, p.69). On the other side of the Atlantic, hydrocarbon discoveries in the Santos, Campos and Espirito Santo basins brought economic notability to the region. The exploration of the new pre-salt layer, between 2013 and 2014, increased Brazilian oil production by 62.7\%. Besides Brazil, Argentina and Colombia, Venezuela stands out with the largest oil reserve (298 billion barrels), especially in the Orinoco basin. The USA is one of the top importers (EIA, 2017).

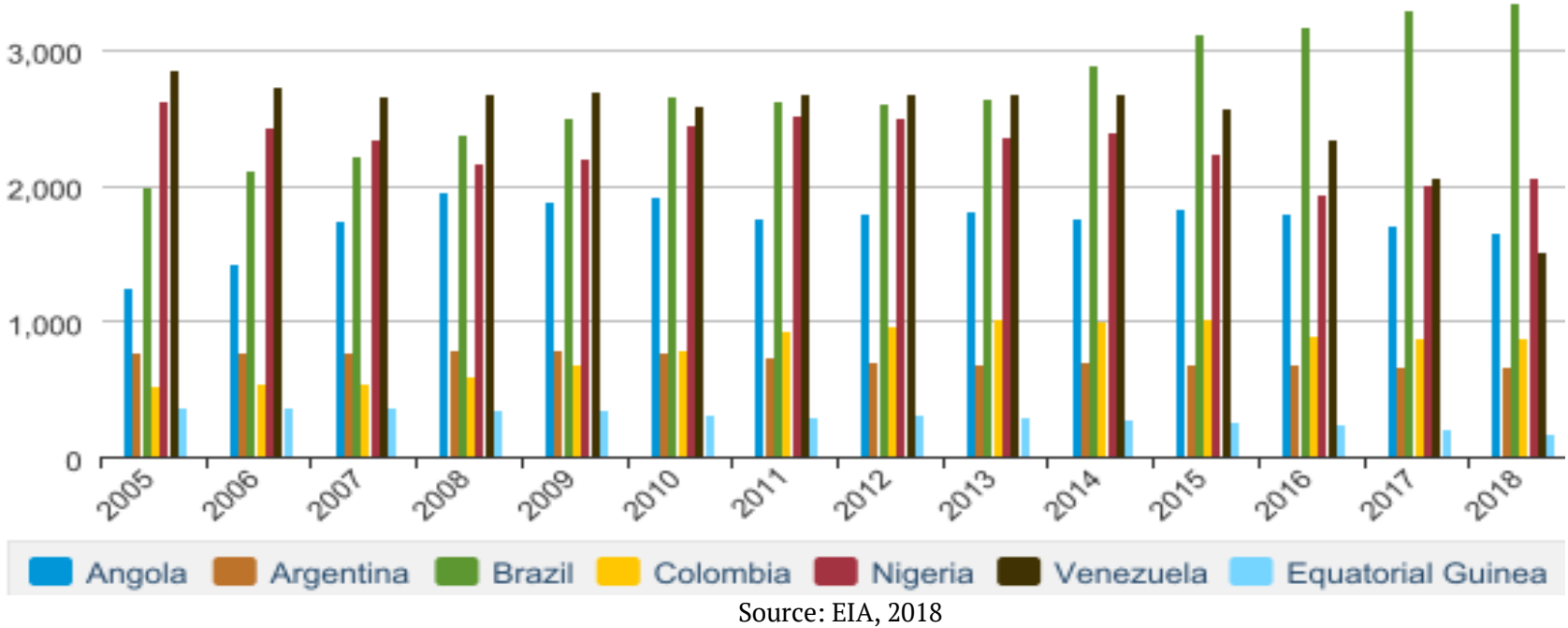

In the South Atlantic, there is abundance of metals, water resources, fishing, fertile land, agricultural and forestry products. Besides the sovereignty of the territorial sea, there is the seabed, rich in metallic compounds (nickel, cobalt, iron, manganese, copper, zinc, silver, gold), and which are not under the jurisdiction of any State. Currently, this area draws attention from England, Germany China, USA, France, Japan, Russia, Australia, South Korea (MARTINS; BARBOZA; ROSA, 2006). It is argued that NATO presence is strategically important in providing mapping and management of natural resources to its members. 
Table 1 - Gem Diamond production (thousands of carats)

\begin{tabular}{|l|c|}
\hline \multicolumn{1}{|c|}{ Country } & $\mathbf{2 0 1 8}$ \\
\hline Russia & 23,000 \\
\hline Botswana & 16,000 \\
\hline Canada & 13,000 \\
\hline Angola & 8,500 \\
\hline South Africa & 7,700 \\
\hline DR Congo & 3,700 \\
\hline Namibia & 1,900 \\
\hline Lesotho & 1,100 \\
\hline Australia & 340 \\
\hline Tanzania & 260 \\
\hline Brazil & 250 \\
\hline Zimbabwe & 250 \\
\hline China & 230 \\
\hline Sierra Leone & 230 \\
\hline Guinea & 140 \\
\hline Other Countries & 480 \\
\hline
\end{tabular}

Source: Geology.com (2018)

Figure2 -Mineral deposits

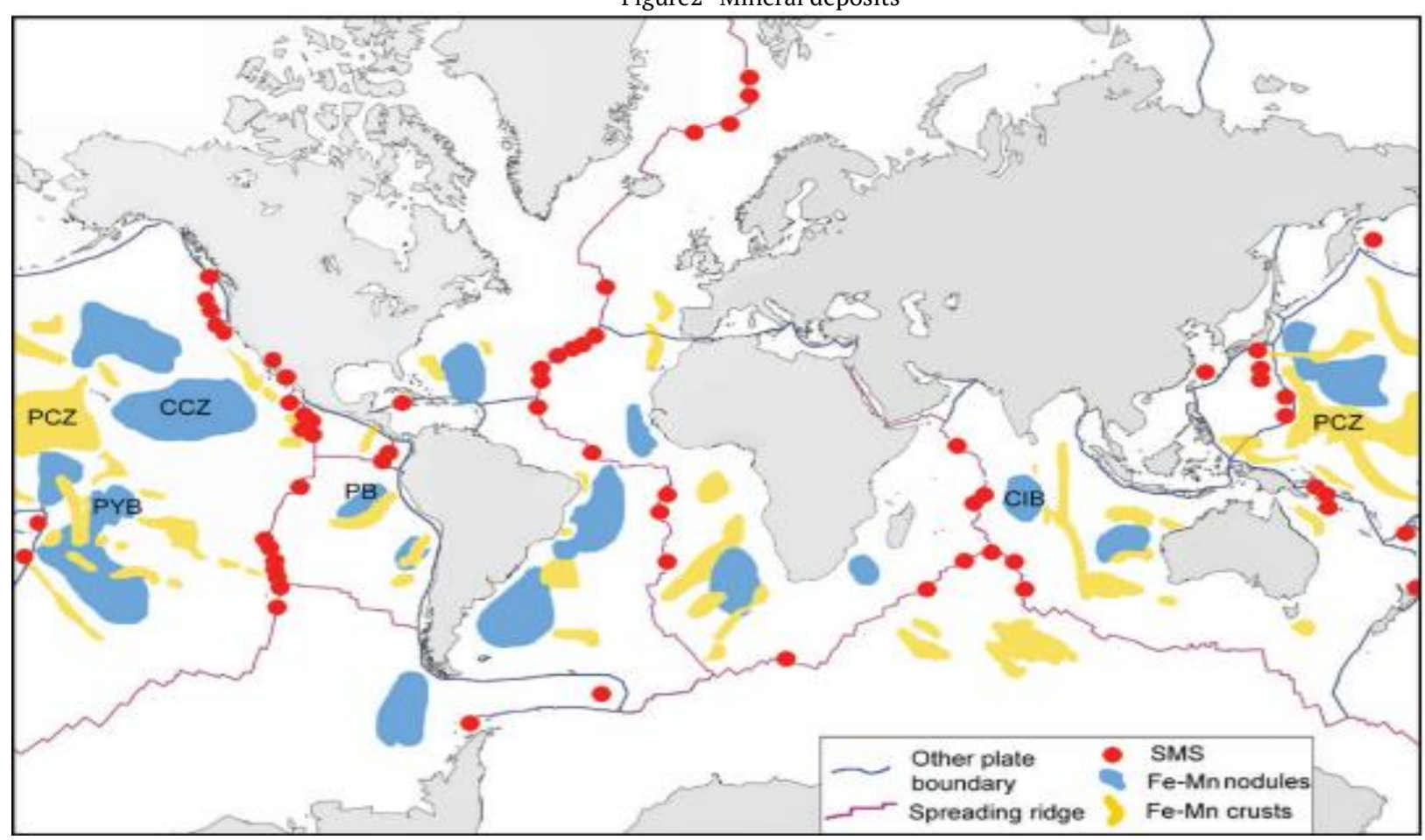

Source: Lusty and Murton (2018)

* SMS: seafloor massive sulfides 
Figure 3 - Water resources

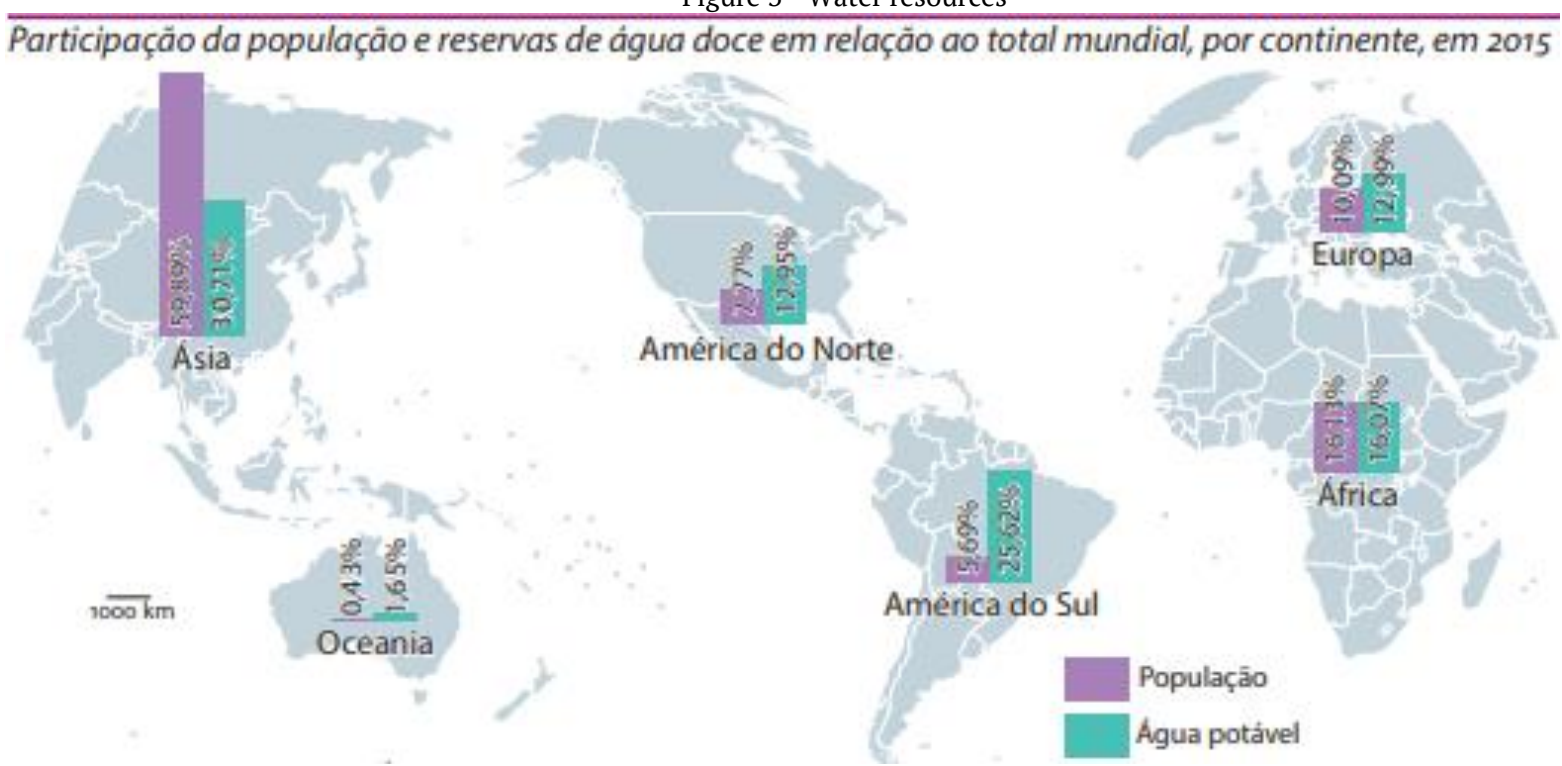

Source: Lima et al (2017)

Figure 4 - Fishing

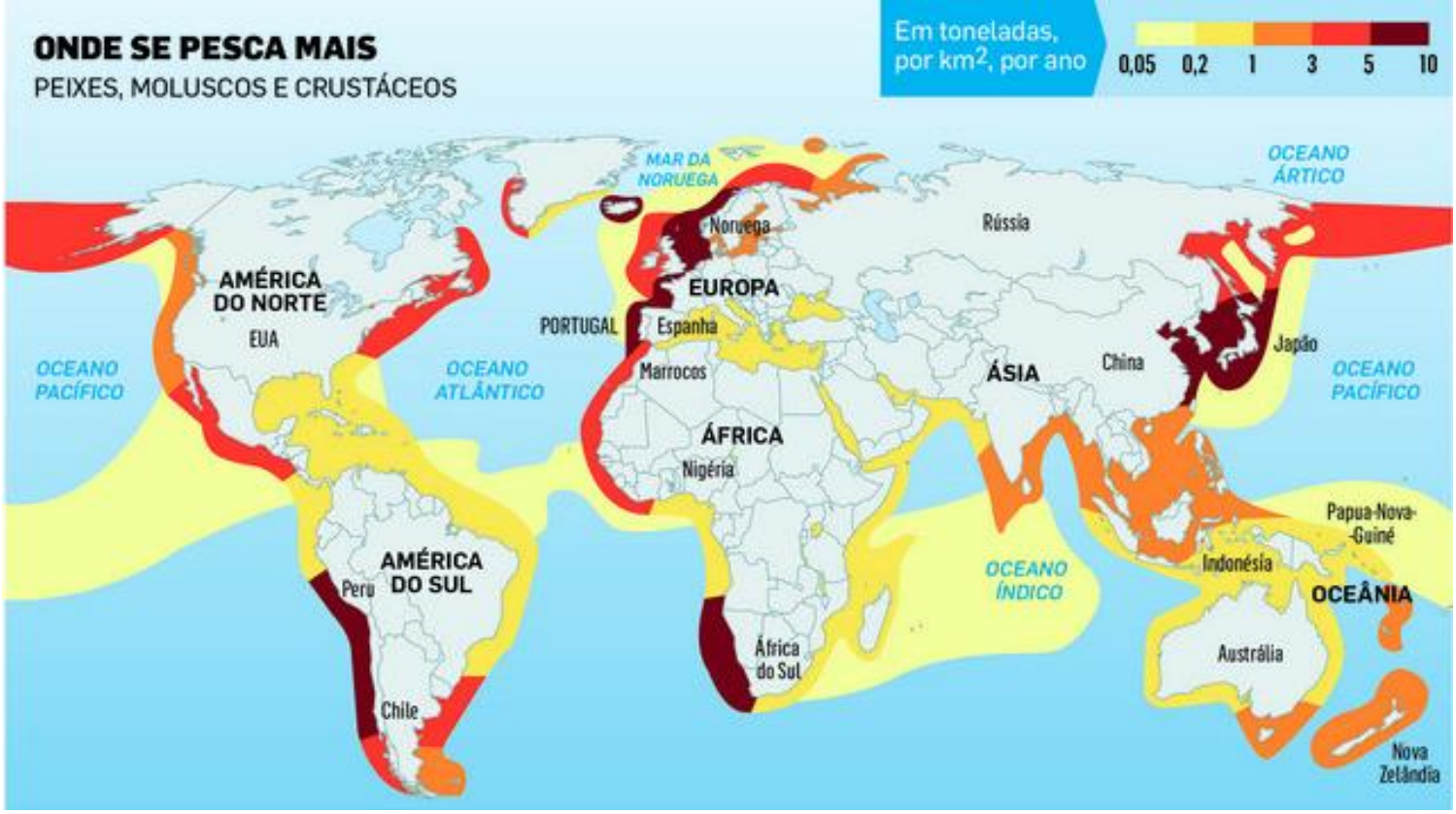

Source: Animal Business Brasil (2017)

As new sources of natural resources appear, the South Atlantic becomes more vulnerable to threats. The South Atlantic has become an important avenue for the illicit trade in drugs, weapons and people. Due to proximity and easy maritime and air access, Colombian drug trafficking and other Latin American cartels use Western Africa as a transit point for high European demand. A Colombian criminal organization, Valencia-Arbelaez, maintained links with drug trafficking in Guinea-Bissau. Former Guinea-Bissau Military Chief António Indjaihad authorized the supply of arms to the FARC in exchange for cocaine (HOFFMAN; LANE, 2013).

The region most affected by piracy is Western Africa, especially the Gulf of Guinea. During the first half of 2013, 31 incidents were reported on the west coast of Africa, with 15 cases occurring in the Gulf in 
the first three months. The concern is that $40 \%$ and $30 \%$ of European and US oil imports, respectively, pass through the Gulf each year (ANYIMADU, 2013). In general, the southern countries don't have adequate policing and surveillance systems to combat piracy. NATO can use structural flaws and structural gaps to justify its presence (LIMA, 2011).

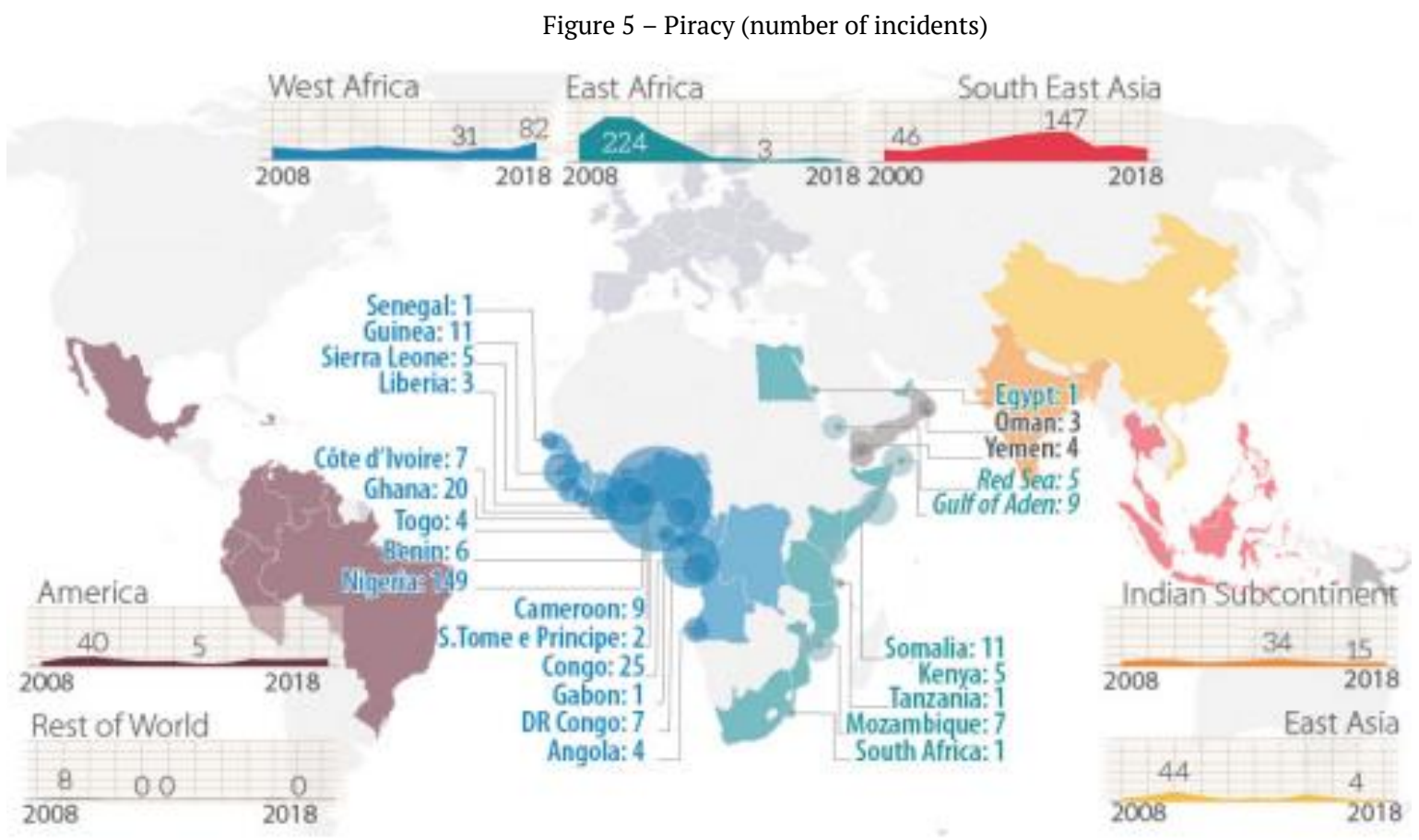

Source: Pichon and Pietsch (2019)

In Western Africa, there are a significant number of terrorist groups. The practice spread from the Sahel region to the Atlantic coast of the South Atlantic and the Red Sea (FATF; GIABA, 2013). In 2011, in Abuja, Boko Haram planned a suicide attack in the UN building and, since July 2009, it has killed about 20,000 people (RAY; GALLAGHER, 2016). In 2013, Ansaru's members group were responsible for the kidnapping of seven foreigners who worked in the Bauchi state construction company (ONUOHA; EZIRIM, 2013). It is speculated that the theft of oil and maritime piracy in the Gulf of Guinea are sources of funding for these organizations.

Another challenge is the activity of armed insurgent groups. In 2005, the Movement for the Emancipation of the Niger Delta came out to claim rights to participate in oil revenues. The group uses attacks on oil facilities, oil pipelines and offshore platforms to disrupt energy distribution (ALI, 2014). On the other side of the Atlantic, there are militant groups that claim rights and political changes. In Colombia, the formation of the FARC and other armed groups marked an environment of disputes with the government, implying internal violence. These groups use guerrilla tactics such as kidnappings, attacks on government facilities, and on infrastructures such as oil and gas platforms and companies (PEREIRA, 2015). These evidences serve the narrative of a threat to energy security, opening space for NATO military projection in the region. 
Finally, as other extraregional actors such as China, India and Russia gain influence in the region, NATO members become concerned about the competition for resources and political influence. These countries have strategic agendas based on investments, subsidies, credit lines, development aid programs, and commercial relations (CHERU, 2014). The expansion of Chinese investment in the extractive industries is in part due to the decline in US participation in the region (RAY; GALLAGHER, 2017). Therefore, "the South Atlantic for China is another key element in its strategy of securitizing energy supply, as in other regions of the world such as the Middle East or Central Asia" (DUARTE,2016, p.113, our translation). Companies invests in mapping the seabed, especially near the Gulf of Guinea, and provide technology to explore deep layers of resources (ABDENUR; SOUZA NETO, 2013b).

Since China has almost $90 \%$ of its trade by sea, the idea is to build a strong navy extended at strategic points. There are projects to install 18 naval bases, three of them in the South Atlantic, near Angola, Namibia and Nigeria (NEVES, 2013; KODA, 2017). Therefore, "The South Atlantic is both a market and a trade route of extraordinary importance for emerging countries such as China” (DUARTE, 2016, p.116, our translation). The inclusion of the South Atlantic in the New Chinese Silk Road plan may be a response to the US projection on Asia-Pacific (PINO, 2013).

Furthermore, the India, Brazil and South Africa (IBAS) forum includes an arrangement among the navies of the three countries, known as Ibsamar. Joint naval exercises are allowed, which challenges the Euro-Atlantic system and strengthen security cooperation (FLEMES; VAZ, 2011). The intensification of Ibsamar contributes to the removal of any form of NATO relationship with regional countries and their naval forces (PRYCE, 2014).

Unlike India and China, Russia has abundant reserves of energy and minerals. The difficult access and high costs of exploring reserves in the Arctic and eastern Urals lead the Russians to pursue an economically viable option (GILES, 2013). Operating costs in Africa and other areas of the South Atlantic are advantageous. The US Southern Commander (Southcom) John Kelly said that "it has been three decades since we last saw this type of high-profile Russian presence” (FARAH; REYES, 2015, p.102). Russia encourages bilateral trade and the sale of military equipment. After the conflict in Georgia in 2008, Russia sent bombers with nuclear capability to Venezuela. A month later, four Russian ships were sent to joint activities with the Venezuelan navy. In 2014 and 2015, the Russian defence minister's visit to Venezuela was aimed at accessing the ports and aerodromes of the territory and the installation of permanent bases for logistics (FARAH; REYES, 2015; ELLIS, 2015). Thus, NATO projection serves the foreign policy objectives of its members in reiterating their power positions over the South Atlantic against the attempt of China, Russia and India occupy strategic gaps. This reinforces the realist view that the level of competition for security and power varies according to the structural distribution of power capacity (WALTZ 2000).

\section{The South Atlantic in the post-Cold War}

In the last decades, NATO presence in the South Atlantic reflects the transformations brought by the strategic concepts and the consolidation of its global agenda. Within the framework of global strategic 
partnerships, NATO cooperates on an individual basis and expects its partners to contribute militarily to its operations by attempting to integrate the space for political dialogue and Western security architecture. Although the partners share concerns and may access NATO activities, it is not safeguarded by Article 5 . Unlike member status, an aggression to the partner's territory does not imply the organization's commitment to respond collectively. Moreover, they don't hold equal powers in NATO decision-making (EDSTRÖM; MATLARY; PETERSSON, 2011).

In June 2013, NATO and Colombia signed the Agreement on the Security of Information (TASE, 2014). The document, not ratified, established a sharing of intelligence and military knowledge. Faced with irregular warfare and drug trafficking, Colombian military has gained experience in demining, explosive weapons and air policing. This may add skills to NATO in similar situations of civil war in other locations (HELBIG; LASCONJARIAS, 2017). In 2018, Colombia became the first Latin American country to formally acquire NATO global partner status as it happened with Japan, Australia and New Zealand. There are criticisms from neighbouring countries (especially Bolivia and Venezuela) about Colombia becoming a 'NATO beachhead' in the region (SANCHEZ, 2014).

The interest of some NATO members in relation to Colombia can be explained by factors such as interest in strategic resources and contesting Russian influence thus it is rooted in a realist geopolitical calculus. Colombia has become the fifth largest exporter of oil to the US market (EIA, 2017). In 2013, Russian bombers carrying nuclear warheads flew over the Colombian island of San Andrés to VenezuelaNicaragua, which irritated the USA (HELBIG; LASCONJARIAS, 2017). Thus, the partnership emerges as a rearrangement of forces in the region in order to contrast Russian advances.

On the other side of the Atlantic, Mauritania is a partner of the Alliance, within the larger arrangement of the Mediterranean Dialogue (MD). In the 1990s, Spain, Italy and France raised concerns about peripheral nations in southern Europe as a likely area of emerging threats linked to terrorist activities, increased migration and the WMD (NATO, 1991). Since 1994, the MD has been a strategic instrument under NATO command to ensure control of security issues and influence on policy decisions in the region. Mauritania is the only MD country to belong to the South-Atlantic coast. Due to the flow of oil and other goods passing along its coast and Mediterranean, NATO presence, according to the members, enhances maritime and energy security (DOKOS, 2008). One year before the expected oil production in Mauritania, NATO decided to send warships claiming that terrorist attacks were unpredictable and that there was a strong need to strengthen defence in the region (JOURDE, 2007).

In 2007, Mauritania was included in the NATO Science for Peace and Security Program (SPS). The aim was to enable participating countries to act quickly in the face of emergency crises and to ensure civil protection. NATO provides modern communication equipment and materials that help with monitoring, emergency tracking and information gathering at national level (NATO, 2017).

In Cape Verde, from 15 to 28 June 2006, NATO led a military exercise known as Steadfast Jaguar. It gained notability through the mobilization of submarines, warships, aircrafts, new mobile communications information systems, ships from the sixth North American fleet of Mount Whitney, plus German, French, 
Spain, American, Belgian, Luxembourg and cape verdean military personnel (LINDSTROM, 2007). The goal was to test the efficiency and flexibility of NATO Response Force (NRF); a modern military structure developed to fit the reality of out of-area operations. In the Santo Antão and São Vicente islands, exercises with infantry were promoted and interaction of naval, land and air forces was tested. In the São Vicente island, it was implanted a NATO logistics base, concentrating medical arsenal and all the necessary infrastructure. In the Salt island, air activities were executed due to the location of the main archipelago's airport. Finally, a civil emergency operation, called Volcano 2006, was carried out and had a Cape Verdean civil protection service to simulate the volcanic eruption and local evacuation (VARELA, 2007).

According to Former NATO Commander James Jones, the exercise projected the NRF near Western Africa to provide maritime monitoring of oil tankers and energy installations in the Niger Delta (AMES, 2006). The archipelago is in an area of intense maritime and air traffic and near important natural resources. It is a transit area for drugs and other illicit activities (MADEIRA; MONTEIRO, 2016). In 2009, then US Secretary of State Hilary Clinton declared, "Faced with Cape Verde's geostrategic position on the Atlantic Ocean corridor, the USA will increase its support in the fight against the various types of trafficking: drugs, arms and people" (apud ARENA, 2010, our translation). It is noteworthy that Cape Verde was chosen from a countries' list (Mauritania, Canada, Ghana, Gabon, Iceland) to promote this military activity, four of which are in the South Atlantic. Although there aren't substantial links between NATO and Cape Verde since 2006, an already built military relationship can facilitate NATO re-engagement with the country in the face of possible future needs, especially because of its geostrategic location. "NATO has other objectives not yet assumed or still unpronounceable playing against the potentialities and vulnerabilities of Cape Verde”, as quoted by Varela (2007, p.18, our translation).

In the same way that NATO promotes military activities in the South Atlantic under its official command, there are situations in which the organization only provides resources for member-led bilateral programs. In October 2005, Spanish, American and Italian contingents made available by NATO and Ghanaian forces carried out joint training exercises (MODERN GHANA, 2005; EUCOM, 2011). This mission is the result of the West African Training Cruise, a regular military practice between the USA and Western African on security issues. The US Navy organizes visits to the ports of these nations, promoting training, military exercises and maritime awareness. In 2007, through the NATO naval fleet, the US co-ordinated an operation for nearly two months. Ships from the Standing NATO Maritime Group One were used to monitor the Gulf of Guinea and the coast of South Africa, following similar patterns to the US operation Obangame Express (Gulf of Guinea). Alliance participated in the Amazolo exercise with the South African navy in which ships from USA, Germany, Holland, Canada, Denmark and Portugal were supplied from the NATO arsenal (PORTS AND SHIPS, 2007).

Since the post-1989, NATO has experienced distinct phases of engagement with the world according to its respective priorities and current needs. The set of training, partnerships and supply of military arsenal in this regional environment represents a way of consolidating its global role, in projecting influence and reinforcing the members power distribution. However, these initiatives do not make up for an active NATO 
strategic design for the South. This can be observed in the organization's official documents (1990-2018) which refer to northern Africa and Sahara-Sahel issues, but do not present specific guidance for the South Atlantic. Part of the lack of strategic clarity may relate to institutional subordination to national interests, priorities in other areas, and the Alliance's functionality in responding to the needs of the moment. However, this gap does not mean the South Atlantic is not relevant to NATO global security agenda.

\section{Interests of the Members}

After mapping the South Atlantic to understand the type of involvement and the role that NATO occupies, we now move on to investigate what are the specific members' interests. The USA will seek to reduce its active role in the military and economic arena of the international environment in the next decades. However, to prevent that the withdrawal of their presence produces a power vacuum and diminishes theirs influence in the world, the USA may consider expanding the NATO role in filling these gaps (SOLLER, 2010). This argument is present in a study of the US National Security Strategy and the Albright Report, prepared in 2010 by Madeleine Albright and requested by the NATO Secretary-General.

Furthermore, it is noteworthy the US strategic view for the South Atlantic. The region is an excellent alternative for oil supply. The creation of the unified combat command of Africom in 2007 shows this reality, as well as the document Security Strategy 2006: "Africa holds growing geo-strategic importance and is the high priority of this Administration" (UNITED STATES, 2006, p.37). Africom aims to secure access to natural resources in Africa, to prevent activities of armed groups that are harmful to the free flow of these resources, and to avoid the growing influence of China (MESFIN, 2009).

The reactivation of the Fourth Fleet in 2008 represented the USA' quest to strengthen its power projection over the South Atlantic. The Fleet was created in 1943 to protect the Panama Canal and to prevent the presence of German warships and submarines. Its reestablishment was due to the discovery of oil fields and the presence of other extraregional actors in the South Atlantic that could undermine the exclusive supply of resources to the USA (MACLAY et al, 2009). Like Africom and the Fourth Fleet, NATO employment in this area would be one of the US projection mechanisms to reinforce interests, but with a multilateral nature that influences the legitimacy.

However, the current US foreign policy has broken with some policies of previous years. In the Donald Trump administration, there is a notable retreat in the commitment to European security issues. The president threatened to withdraw forces from the continent in case the Europeans resist in increasing their defence spending. Trump has questioned US commitment to NATO Article 5, the first president to do so (SULLIVAN, 2018). In addition, the "America First" approach undermines the confidence of other countries in the USA, especially considering the Trump's administration diminished political will to support multilateral institutions (KAUFMAN, 2017). NATO preservation is under threat when Trump declared the organization was obsolete and considered the US withdrawal from the Alliance in 2018 (SANTORA, 2018).

British interests in the South Atlantic are mostly related to its overseas territories which involve the Falkland Islands, St. Helena, Ascension, Tristan da Cunha, South Georgia, South Sandwich. These territories 
are strategic points that serve as military logistical bases for the economic exploration of natural resources and scientific research. The Falklands Islands, according to Dodds (2013), are Britain's third priority after the UK and Afghanistan and are considered 'strategic gateways' in the South Atlantic. This archipelago contains a Royal Air Force Mount Pleasant military base which involves modern fighter-bomber Typhoon (DODDS, 2012). In the Ascension Island, the base area of Wideawake was established and managed by the USA since 1942 and operated in partnership with British and NATO air forces. In this island there is a global electronic surveillance system that intercepts signals and communication networks, allowing greater strategic coordination on the South Atlantic (WILTGEN, 2013). To consolidate military projection, the British employ personnel from the navy, army, air force, Royal Fleet Auxiliary and arsenal of frigates by the Atlantic State Patrol Task Force (UNITED KINGDOM, 2012).Consequently, NATO presence has a complementary role in maintaining British interests in the region.

To a lesser extent, France projects its influence in the South Atlantic through the overseas department of French Guiana. Since 1964, satellites have been launched into space by the Guyana Space Centre in Kourou. In 1975, France in partnership with the European Space Agency encouraged the launching of satellites in that territory, ensuring Europe's access to space. The base is enhanced by modern Souyz and Vega rockets (HOWELL, 2016). Both French and British Overseas Territories help maintain control over the region and serve as a basis for future NATO operations in the South Atlantic (SILVA, 2014).

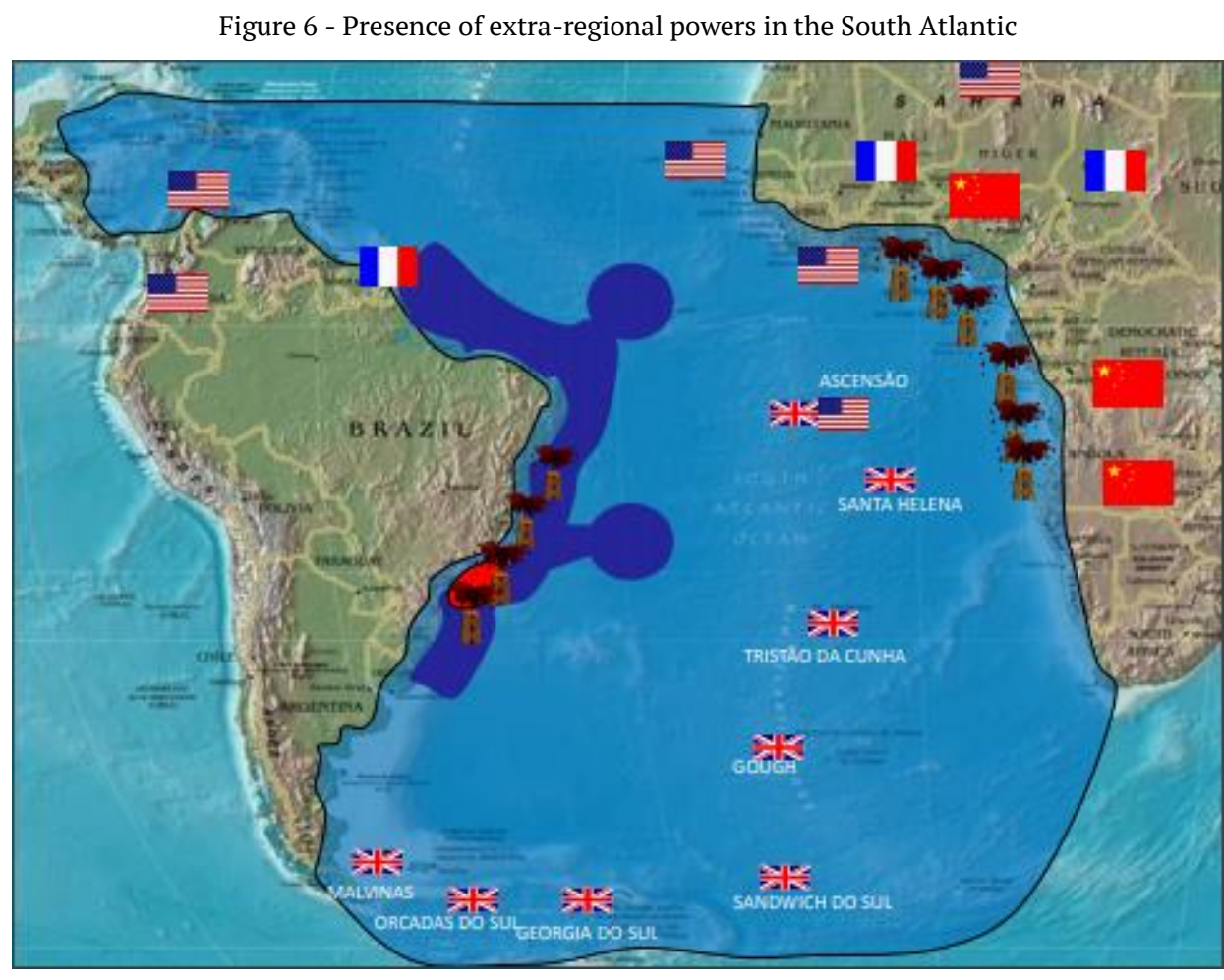

Source: Penha (2016)

For Portugal, the South Atlantic resurfaces as a strategic area for the goal of energy autonomy. The country seeks to re-establish ties with ex-colonies through regional cooperation agreements. The 
Portuguese foreign policy is based on three directives: Europeanist, Euro-Atlantic and Atlantic, in other words, Portugal is involved in diverse regional dynamics as materialized through by NATO, EU and the CPLP. The country could assume the role of articulator between several regional forums and create interoperability between the North and South Atlantic. Within NATO, Portugal is one of the main promoters of the unification of the oceans. The Portuguese Minister Luís Amado pointed out in 2009 that South Atlantic security issues should be incorporated into the agenda of the Alliance and the EU to better ensure free transit of natural resources (ALHAIS, 2017; SERRONHA, 2010). According to the Strategic Concept of National Defence of Portugal (2013):

\begin{abstract}
The two shores of the South Atlantic have been subject to intense demand for energy, minerals and food, underscoring their geoeconomic relevance. The reserves of the Gulf of Guinea and Angola and the offshore oil and gas deposits in Brazil represent a counterweight to the traditional power centres in the international energy system. The Atlantic, as well as being a capital platform for the flow of raw materials and energy, will be even more valued for being an open ocean. The growing importance of energy and commercial routes highlights the need for a convergent effort between the North and South coastal countries to ensure their common security (PORTUGAL, 2013, p.1920, our translation).
\end{abstract}

Portugal's military dependence on NATO structure is evident from its global security and defence interests. The Spanish and Portuguese believe that strengthening historical and cultural ties with southern countries could facilitate the integration with the North Atlantic. As a matter of fact, they would guarantee greater voices within Alliance and encourage the NATO renewal (SEABRA, 2014). Even with Portuguese pressures, the Lisbon Concept (2010) did not explicitly involve the South Atlantic in the document as a prominent area for security, rescuing the realist principles that less powerful members have less bargaining power in institutions.

Discussions about the South and North Atlantic integration were present in the 'Shoulder to Shoulder: Forging a Strategic U.S.-EU Partnership' produced by scholars Daniel S. Hamilton and Frances G. Burwel in 2009. Among the many issues treated within the EU-US partnership, it highlights an initiative to "erase the historical line that divides the North and South Atlantic", known as the Atlantic Basin (HAMILTON; BURWELL, 2009, p.68). The authors' justification is that there is an interdependence between northern and southern emerging powers, especially regarding energy matters. Countries want free and secure access to resources in Latin America and Africa (HAMILTON; BURWELL, 2009).The implementation of the Atlantic Basin Initiative would give greater control and influence on the USA and European countries on economic, political, security and energy issues in South Atlantic. It would mean openness to using NATO when intervention is required (LIMA, 2011).

\title{
Perspectives of regional actors
}

NATO involvement in the South Atlantic is a source of concern for regional powers. For Brazil, the region is an important trade channel, represents an extension of its security, involves enormous marine diversity and natural resources such as oil. Through the latest Brazilian documents National Defence Strategy (2008) and Defence White Paper (2012), the country seeks to strengthen maritime defence policies, 
modernize its military arsenal, establish aerodrome ship construction projects, conventional and nuclear submarines and radars, satellites and patrol vessels (BRAZIL, 2012).

Figure7 - Brazilian geopolitical perspective

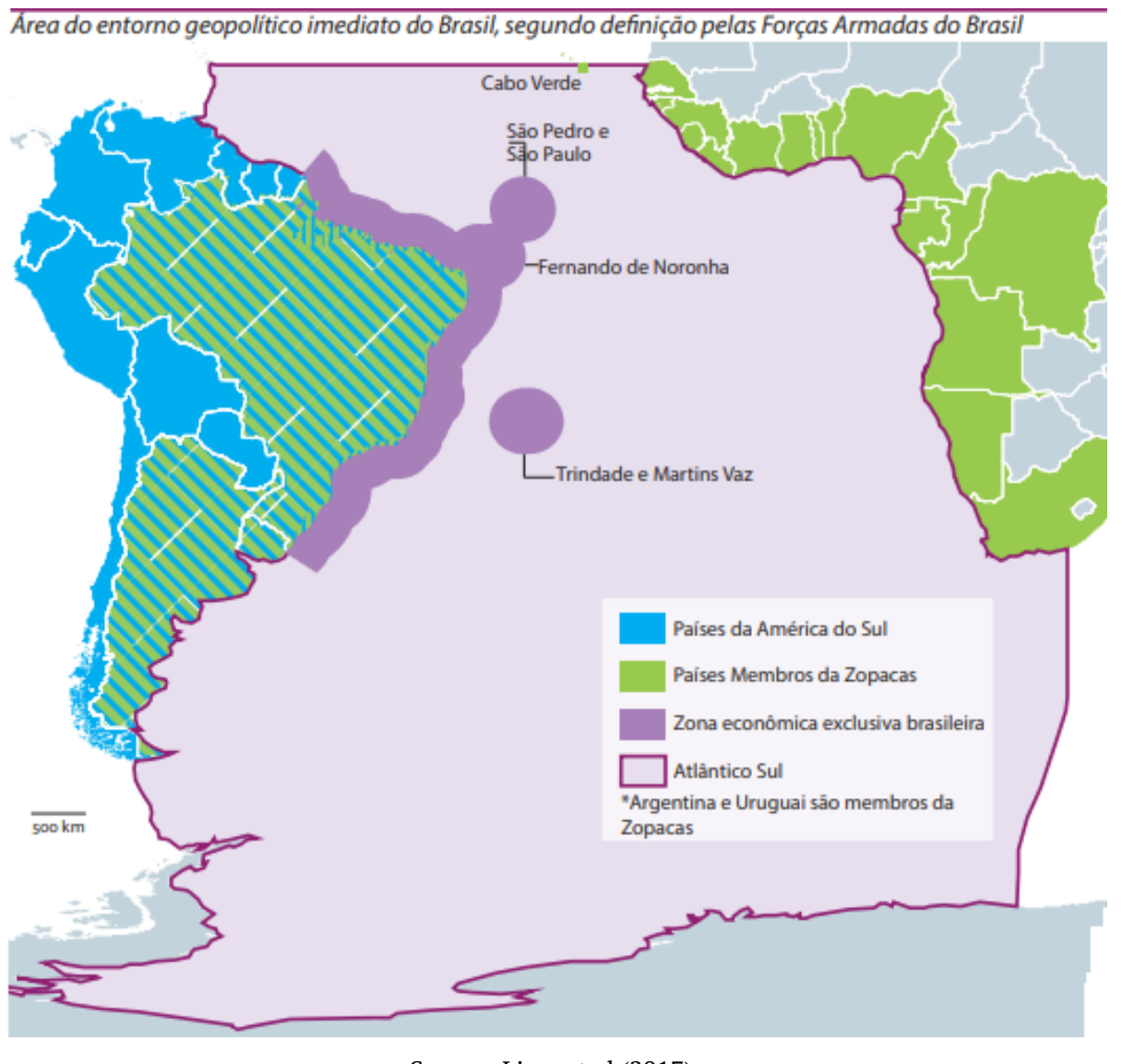

Source: Lima et al (2017)

The South Atlantic is an instrument of Brazilian power projection thus there are efforts to prevent extraregional actors from instituting a military presence. NATO presence is seen as a mechanism for US foreign policy to legitimize its operations abroad and is understood as a tool to access natural resources of the seabed, undermining Brazilian interests in building a transatlantic community and becoming an actor at the regional and global level. This distrust was present in the Lula and Dilma governments .A partnership between Brazil and NATO would mean continuing to submit to US interests (ABDENUR; HERZ, 2015).

The Michel Temer administration and, above all, the current government of Jair Bolsonaro has favoured a closer relation with the USA. There is a clear intention to make Brazil a strong ally of the Americans. Recently, an agreement signed between the two countries, aims to allow the US to launch satellites from the Alcântara base, in Maranhão. In addition, Trump intends to designate Brazil as nonNATO ally and has even mentioned the possibility to allow it to be part of the Alliance. For Ernesto Araújo, the Brazilian Foreign Minister, this status would benefit Brazil's defence industry (JORNAL DE NOTÍCIAS, 2019).

Argentina has presented different positions vis-à-vis NATO. During Carlos Menem's administration, a seminar on global security issues was held inviting high-level NATO officials. In 1998 the country sent 
troops and participated in the NATO-led Stabilization Force in Bosnia and Herzegovina (MERKE, 2011). The Argentine involvement in Kosovo meant a high degree of interaction with NATO, with an Argentine officer as a liaison at the Supreme Headquarters Allied Powers Europe (SHAPE). In 1999, President Menem sent a letter to Bill Clinton and the North Atlantic Council (NAC), expressing interest in formally joining the Alliance. This position would give Argentina a counterbalance to the advance of Brazilian power and a greater voice in the negotiations with England on the Falklands Islands. However, NATO refused Menem's request, since accession would mean reforming the Washington Treaty delimitation to the North Atlantic countries (REFICCO, 1998). In Néstor Kirchner's government (2003-2007), relations with NATO lost priority. This posture was reaffirmed in 2014 when Cristina Kirchner looks at the NATO presence as an instrument of British foreign policy towards the Malvinas (EFE, 2014).

The recent policies of Mauricio Macri's government have strengthened ties with the USA, reconsidering it as a strategic partner. Argentina already has non-NATO ally status, which was obtained in 1997. According to Argentina Reports, Macri allowed US military entry to instruct the Argentine police and the installation of three US military bases in Misiones, Tierra del Fuego and Neuquén, financed by Southcom (JENNER, 2018).

A security and defence cooperation agreement signed by 24 southern countries has existed since 1986 in order to counterbalance the military presence of extraregional actors and guarantee voice and security of the Global South. The South Atlantic Peace and Cooperation Zone (Zopacas) is also an initiative to neutralize the projection interests of a Global NATO. The VI Meeting in Luanda (2007) promised to revitalize the agreement, the South-South cooperation and signalled a reaction to discussions on the possible involvement of the entire Atlantic basin in the NATO zone of influence (ABDENUR; HERZ 2015).

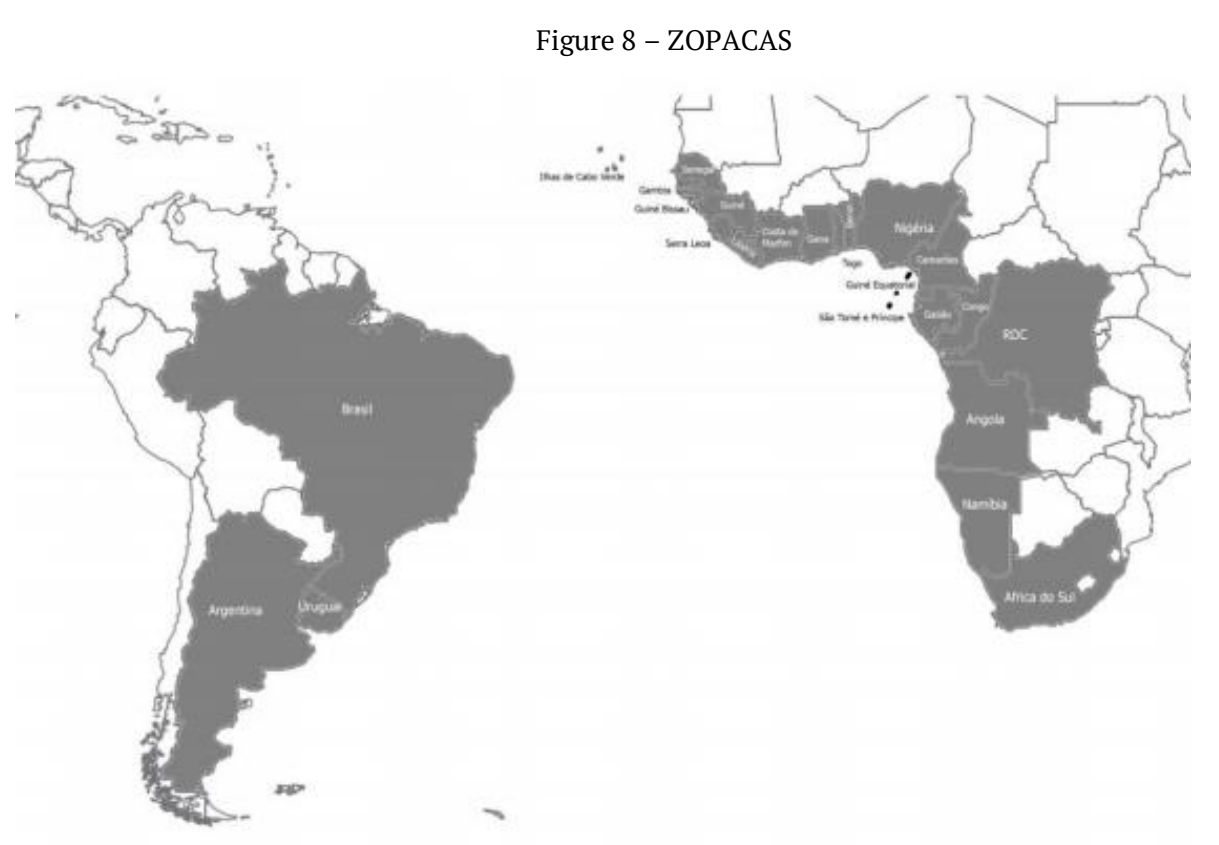

Source: Penha (2016) 
Although British Overseas Territories and Norway's Bouvet Island in the region are not covered by international treaties that prohibit nuclear weapons, Zopacas's role is to reinforce the nuclear weapon free zone and de-securitise the region. The goal is to prevent the South Atlantic from being involved in great powers military activities and conflicts. The VII Meeting held in Uruguay (2013) was essential for two reasons: it had the participation of the member states' defence ministers and produced two documents (Declaration of Montevideo and the Plan of Action) that strengthen the commitment to the Declaration of the South Atlantic Denuclearization Zone (1994). This consolidate a stance against the presence of nuclear powers in the area (BRAZIL, 2013).

\section{Conclusion}

This article examined the motivations of involving NATO as a military organization managed by the USA and European countries in the South Atlantic. As discussed, through the partnerships with Colombia and Mauritania, NATO members gain control and influence over regional security decisions and issues. In joint military operations in Cape Verde, Ghana and other African coastal countries, the aim is to map economically promising areas and prevent the presence of other extraregional actors. Degree of NATO involvement is still complementary. It performs activities integrating the regional defence and security system such as training, destruction of obsolete arsenal, monitoring missions, military modernization. NATO has occupied several sectors in the South Atlantic: energy and maritime security, civil emergency, natural disasters, drug trafficking, combat to armed groups. It has become a tool for strengthening the members' military and political presence in that area. However, the organization doesn't yet demonstrate a unified strategy towards the region as it's currently focused on the Middle East, the Mediterranean, Black and Baltic seas.

The South Atlantic appeared on the NATO security agenda in the 1970s because of growing Soviet power projection and of fears that it could obstruct MCLs for the supply of oil and raw materials, especially on the Cape of Good Hope and the Panama Canal. However, NATO remained limited to the commitment of collective defence and the geographical nature of the North Atlantic. The organization only provided resources, monitored activities, served as a consultation forum and participated in contingency plans of the region.

In the current scenario, greater NATO involvement in the South Atlantic has been possible after the transformations of the capabilities and structure that formalized out-of-area missions and led it to assume global responsibilities. The latter Strategic Concept (2010) established that no matter where or when a threat emerges, if it compromises the security of its members, NATO will decide on a case by case basis whether to intervene. Geopolitical interests at stake of the members instrumentalize a Global NATO to impose a security architecture according to its pattern, repel growth of other possible powers and influence regional political decisions. In this sense, the realist theoretical perspective of IR seems appropriate for the understanding of NATO role in the current international scene. 
In this article, we listed three possible explanatory factors for NATO involvement in the South Atlantic. First, in the face of a possible future energy crisis, this area emerges as promising given its abundance of mineral and energy reserves. Second, typical security threats in that area, such as piracy, armed groups, people and drug trafficking, along with a precarious regional defence system, may serve as a justification for NATO intervention. Finally, the growing presence of extraregional actors such as Russia, China and India could undermine the interests of NATO members in the region. In addition, the discussion about the Atlantic Basin Initiative and recent partnership with Colombia indicate that the South Atlantic seems to assume relevance in the national agendas.

The issues advanced in this article raises questions for the future: Will NATO continue to play a limited role in the region, or will it evolve as a more interventionist mechanism in the decades to come? Will the South Atlantic be recognized as a vital area and incorporated into the next NATO Strategic Concepts, with the consequent development of a specific strategy for the region? Considering that the three factors listed in this article tend to become more salient, a positive answer to these questions seems likely. We hope future studies can shed light on this important issue for international relations.

\section{REFERÊNCIAS}

ABDENUR, Adriana E.; HERZ, Monica. Brazilian Reactions to NATO in the Post-Cold War. 2015. In: Academia Edu.

Available at:<https://www.academia.edu/12441696/Brazilian_Reactions_to_NATO_in_the_PostCold_War>. Acesso em: 15 dez. 2017.

ABDENUR, Adriana E.; MATTHEIS, Frank; SEABRA, Pedro. An ocean for the Global South: Brazil and the zone of peace and cooperation in the South Atlantic. Cambridge Review of International Affairs, [S.l.], v. 29, n. 3, p. 1112-1131, Nov. 2016. Available at: <http://dx.doi.org/10.1080/09557571.2016.1230592>. Acesso em: $17 \mathrm{dez} .2017$.

ABDENUR, Adriana E.; SOUZA NETO, Danilo M. de. Brazil's Maritime Strategy in the South Atlantic: The Nexus Between Security and Resources. South African Institute of International Affairs (SAIIA), Johannesburg, n. 161, Nov. 2013a. Available at: <https://www.saiia.org.za/occasionalpapers/463-brazil-s-maritime-strategy-in-the-southatlantic-the-nexus-between-security-andresources/file>. Acesso em: 13 dez. 2017.

ABDEBUR, Adriana E.; SOUZA NETO, Danilo M. de. China's Growing Influence in the South Atlantic. Revista CIDOB d'Afers Internacionals, [S.1], n. 2, p. 169-197, Sept. 2013b. Available at: <https://doaj.org/article/39543fdeee9d4cf8b09fd36007fe9d50>. Acesso em: 05 ago. 2017.

AFDB (African Development Bank). Oil and Gas in Africa. New York: Oxford University Press, 2009. Available $<$ https://www.afdb.org/fileadmin/uploads/afdb/Documents/Publications/Oil\%20and\%20Gas\% 20in\%20Africa.pdf>. Acesso em 28 out. 2017.

ALHAIS, Alexandra. O Atlântico Sul, Portugal e o Conceito Estratégico de Defesa Nacional=The South Atlantic, Portugal andtheNationalStrategicDefenseConcept. CEDIS Direito, Segurança e Democracia, n. 51, fev. 2017. Available at: <http://cedis.fd.unl.pt/blog/project/o-atlantico-sulportugal-e-o-conceito-estrategico-dedefesa-nacional/>. Acesso em: $22 \mathrm{dez} .2017$. 
ALI, Kamal-Deen. The Anatomy of Gulf of Guinea Piracy. Naval War College Review, [S.l], v. 68, n. 1, p. 93-118, Winter 2015. Available at: <https://usnwc2.usnwc.edu/getattachment/e95feaa7-88834008-b49b-175783f25e43/TheAnatomy-of-Gulf-of-Guinea-Piracy.aspx>. Acesso em: 21 nov. 2017.

AMES, Paul. Nato set to flex muscles in Cape Verde exercise. Mail e Guardian, [S.1.], 21 jun. 2006. Available at: <https://mg.co.za/article/2006-06-21-nato-set-to-flex-muscles-incape-verde-exercise>. Acesso em: 03 jan. 2018.

ANIMAL BUSINESS BRASIL. Mapa da pesca no mundo. Oct. 2010. Available at: $<$ https://animalbusiness.com.br/cenario-agro/desenvolvimento/falta-um-plano-eficiente-depesca-no-brasil/attachment/mapa-da-pesca-no-mundo/>Acesso em: 17 jul. 2019.

ANYIMADU, Adjoa. Maritime Security in the Gulf of Guinea: Lessons Learned from the Indian Ocean. Chatam House, London, n. 2, 2013. Available at: <https://www.chathamhouse.org/publications/papers/view/193515>. Acesso em: 21 nov. 2017.

ARENA, Joaquim. Cabo Verde na rota da NATO?. SAPO Notícias, [S.1.], 19 nov. 2010. Available at: $<$ https://noticias.sapo.cv/actualidade/artigos/cabo-verde-na-rota-da-nato>. Acesso em 03 jan. 2018.

ATLÁNTICO Sur, Hoy El Océano Más Pacífico. El País, [S.l.], 28 dic. 2015. Available at: $<$ http://www.elpais.com.uy/informacion/atlantico-sur-hoy-oceano-pacifico.html >. Acesso em: 04 dez. 2017.

BARTOLOMÉ, Mariano C. El ConflictodelAtlánticoSur: lahipótesis de una guerra fabricada. Boletín del Centro Naval, n. 786, Abr-Jun. 1997. Available at: <http://www.centronaval.org.ar/boletin/BCN834/834-BARTOLOME.pdf>. Acesso em 12 jul.2017.

BRASIL. Ministério das Relações Exteriores. VII Encontro Ministerial da Zona de Paz e Cooperação do Atlântico Sul - ZOPACAS - Declaração de Montevidéu. Jan. 2013. Available at: <http://www.itamaraty.gov.br/pt-BR/notas-a-imprensa/3285->Acesso em 17 jul. 2019.

BRAZIL. Ministro da Defesa. Defense White Paper. Brasília, 2012. Disponível em $<$ https://www.defesa.gov.br/arquivos/estado_e_defesa/livro_branco/lbdn_2013_ing_net.pdf > Acesso em: 13 Dec. 2017.

CHERU, Fantu. Emerging Economies and Africa's Natural Resources: Avoiding the "Resource Curse" and Building more Resilient Societies. In: NSI OTTAWA FORUM. 2013, Ottawa. Governing Natural Resources For Africa's Development. [S.l.: s.n.], 2014. p.1-11. Available at: <http://www.nsiins.ca/wp-content/uploads/2014/01/Brief-Cheru-EmergingEconomies-and-Africa\%E2\%80\%99sNatural-Resources.pdf >. Acesso em: 28 set. 2017.

COKER, Christopher. NATO, the Warsaw Pact and Africa. London: Palgrave Macmillan UK, 1985.

DODDS, Klaus. Consolidate! Britain, the Falkland Islands and wider the South Atlantic/ Antarctic. Global Discourse, [S.l.], v. 3, n. 1, p.166-172, mar. 2013. Available at: <http://dx.doi.org/10.1080/23269995.2013.804767> Acesso em: 21 dez. 2017.

DOODS, Klaus. The Falkland Islands as a 'Strategic Gateway'. The RUSI Journal, [S.1.], v. 157, n. 6, p.18-25, dez. 2012. Available at: <http://www.tandfonline.com/doi/abs/10.1080/03071847.2012.750882>. Acesso em: 21 dez. 2017.

DOKOS, Thanos P. NAT O's Mediterranean Dialogue: Prospects And Policy Recommendations. [S.l], 2008. In: Hellenic Foundation for European and Foreign Policy. Available at: <http://www.eliamep.gr/wp-content/uploads/2008/09/dokos-natos-mediterraneandialogue.pdf>. Acesso em: 22 out. 2017. 
DUARTE, Paulo. As Incursões da China na América Latina e Atlântico Sul= China'sIncursions In LatinAmericaAnd The South Atlantic. Brazilian Journal of International Relations, Marília, v. 5, p. 97-123, jan-abr. 2016. Available at: <http://www2.marilia.unesp.br/revistas/index.php/bjir/article/view/5944>. Acesso em: 05 ago. 2017.

ECHENDU, Joseph C.; ILEDARE, Wumi. Energy Resources \& Development: A Case Study of the Gulf of Guinea Region. International Association for Energy Economics, Antalya, May 2015. Available at: <https://www.iaee.org/en/publications/proceedingsabstractpdf.aspx?id=12901>. Acesso em: 08 dez. 2017.

EDSTRÖM, Håkan; Matlary, Janne H; PETERSSON, Magnus. Utility for NATO - Utility of NATO?. In (eds), NATO: The Power of Partnerships. London: Palgrave Macmillan, 2011, p.1-17.

EFE. Malvinenses respondem Cristina Kirchner com ironia. Folha de São Paulo, [S.l], 03 abr. 2014. Available at: <http://www1.folha.uol.com.br/mundo/2014/04/1435572malvinenses-pro-reinounido-respondem-cristina-com-ironia.shtml>. Acesso em: $15 \mathrm{dez} .2017$.

EIA (U.S Energy Information Administration). International Energy Statistics. 2018. Available at: $<$ https://www.eia.gov/beta/international/data/browser/\#/?pa=000000000000000000000000000000 $00008 \& \mathrm{c}=2800020010004000000000000000000400000000000000002 \& \mathrm{ct}=0 \& \mathrm{tl} \_\mathrm{id}=5$ -

A\&vs=INTL.55-1-DZA-TBPD.A INTL.55-1-AGO-TBPD.A INTL.55-1-ARG-TBPD.A INTL.55-

1-BRA-TBPD.A INTL.55-1-COL-TBPD.A INTL.55-1-NGA-TBPD.A INTL.55-1-VEN-

TBPD.A\&cy=2016\&vo=0\&v=C \&start=2005\&end=2018>. Acesso em: 16 jul. 2019.

EIA (U.S Energy Information Administration). This Week in Petroleum. 2017. Available at: <https://www.eia.gov/petroleum/weekly/archive/2017/170405/includes/analysis_print.php>.

Acesso em: 16 set. 2017.

EUCOM. Training enhances partnerships in West Africa. Aug. 2011. Available at: $<$ http://www.eucom.mil/media-library/article/21415/Training-enhances-partnershipsWestAfrica>. Acesso em: 11 jan. 2018.

EUROSTAT. Energy production and imports. June 2017. Available at: $<$ http://ec.europa.eu/eurostat/statisticsexplained/index.php/Energy_production_and_imports\#Imp orts>. Acessoem: 10 jan. 2018.

FARAH, Douglas; REYES, Liana E. Russia in Latin America: A Strategic Analysis. Prism, v.5 n.4, p.101-117, 2015. <http://cco.ndu.edu/Portals/96/Documents/prism/prism_54/Russia\%20in\%20Latin\%20America.pdf $>$ Acesso em 21 Nov. 2017.

FATF; GIABA. Terrorist Financing in West Africa. Paris, Oct.2013. Available at: <http://www.fatfgafi.org/media/fatf/documents/reports/tf-in-west-africa.pdf>. Acesso em: 20 nov. 2017.

FLEMES, Daniel; VAZ, Alcides Costa. Security Policies of India, Brazil and South Africa:Regional Security Contexts as Constraints for a Common Agenda. German Institute of Global and Area Studies, $\mathrm{n}$. 160, p. 6-25, $\quad$ Feb. 2011. Availableat: <https://www.gigahamburg.de/de/system/files/publications/wp160_flemes-vaz.pdf> Acesso em: 07 dez. 2017.

GARCÍA RAMÍREZ, Juan David. La transformación de la OTAN a través de los conceptos estratégicos y laampliación. Analecta política, v. 5, n. 6, p.81-98, enero-junio 2014. Available at: <https://revistas.upb.edu.co/index.php/analecta/article/view/2438> Acesso em: 10 jun. 2017.

GEOLOGY. COM. Which Countries Produce the Most Gem Diamonds?.2018. Available at: <https://geology.com/articles/gem-diamond-map/>. Acesso em: 16 jul. 2019. 
GILES, Keir. Russian Interests in Sub-Saharan Africa. Carlisle: Strategic Studies Institute and U.S. Army War College, 2013, 51p. Available at: <http://ssi.armywarcollege.edu/pdffiles/pub1169.pdf>Acesso em: 08 out. 2017.

HAMILTON, Daniel S.; BURWELL Frances G. Shoulder to Shoulder: Forging a Strategic U.S.-EU Partnership. Washington: Center for Transatlantic Relations SAIS, 2009. Available at: <http://streitcouncil.org/uploads/PDF/ShouldertoShoulder.pdf>Acesso em: 02 abr. 2011.

HELBIG, Robert; LASCONJARIAS, Guillaume. Winning Peace and Exporting Stability: Colombia as NATO's next Global Partner?. NATO Defense College, Rome, n. 138, May 2017. Available at: <http://www.ndc.nato.int/news/news.php?icode=1056>Acessoem: 28 jul. 2017.

HOFFMAN, Max; LANE, Conor. Guinea-Bissau and the South Atlantic Cocaine Trade. [S.l], 22 Aug. 2013. Center for American Progress. Available at: $<$ https://www.americanprogress.org/issues/security/reports/2013/08/22/72557/guinea-bissauandthe-south-atlantic-cocaine-trade/>. Acesso em: 26 nov. 2017.

HOWELL, Elizabeth. Guiana Space Center: Europe's Spaceport. [S.l], 2 Sept. 2016. In: Space.com Contributor. Available at: <https://www.space.com/33949-guiana-spacecenter.html>. Acesso em: 26 dez. 2017.

HURRELL, Andrew. NATO and the South Atlantic: A Case-Study in the Complexities of Out-of-area Operations. In: COKER, Christopher (Ed.). The United States, Western Europe and Military Intervention Overseas. Lonon: Palgrave Macmillan UK, 1988, p. 61-84.

HURRELL, Andrew. The Politics of South Atlantic Security: A Survey of Proposals for a South Atlantic Treaty Organization. International Affairs, v. 59, n.2 (Spring, 1983), p. 179-193. Available at: <http://www.jstor.org/stable/2619934>Acessoem: 17 jul. 2019.

JENNER, Frances. Argentina enters into "carnal relations" with the US military. Argentina Reports, Jul 2018. Available at: <https://argentinareports.com/argentina-enters-into-carnal-relations-withthe-us-military/1509/>Acessoem: 18 jul. 2019.

JORNAL DE NOTÍCIAS. Donald Trump quer Brasil como aliado na NATO. Mar 2019. Availableat: $<$ https://www.jn.pt/mundo/interior/donald-trump-quer-brasil-como-aliado-na-nato10701583.html> Acesso em: 18 jul. 2019.

JOURDE, Cédric. Constructing Representations of the 'Global War on Terror' in the Islamic Republic of Mauritania. Journal of Contemporary African Studies, [S.1], v. 25, n.1, p. 77100, Jan. 2007. Available at: <http://dx.doi.org/10.1080/02589000601157089>. Acesso em: 20 out. 2017.

KAUFMAN, Joyce P. The US perspective on NATO under Trump: lessons of the pastand prospects for the future. International Affairs, [S.1], v. 93: n.2, p.251-266, Mar. 2017. Available at: $<$ https://www.chathamhouse.org/publication/ia/us-perspective-nato-under-trump-lessons-pastand-prospects-future> Acesso em: 20 jul. 2019.

KITCHEN, Veronica M. 'NATO's out-of-area norm from Suez to Afghanistan'. Journal of Transatlantic Studies, $\quad$ v.8, $\quad$ n.2, $\quad$ p.105-117, $2010 . \quad$ Disponível em <https://www.tandfonline.com/doi/abs/10.1080/14794011003760269> Acesso em: 20 Set. 2018.

KODA, Vice AdmiralYoji. China's Bluewater Navy Series: China's Blue Water Navy Strategy and its Implications. Center for a New American Security. Washington, Mar. 2017. Available at: <https://s3.amazonaws.com/files.cnas.org/documents/Koda_BWN.pdf?mtime=201703202204 24>. Acesso em: 30 set. 2017. 
LIMA, Marco Aurélio de Andrade. A Iniciativa da Bacia do Atlântico: um risco para o Brasil?. 2011. 44f. Monografia apresentado como requisito para aprovação do Curso de Altos Estudos de Política e Estratégia, Departamento de Estudos, Escola Superior de Guerra, Rio de Janeiro, 2011. Availableat: <http://www.esg.br/images/Monografias/2011/LIMAM.pdf> Acesso em: 23 dez. 2017.

LIMA, Maria Regina Soares de et al (org.). Atlas da política brasileira de defesa. Ciudad Autónoma de Buenos Aires: CLACSO;Rio de Janeiro: Latitude Sul, 2017. Availableat: <http://biblioteca.clacso.edu.ar/clacso/se/20170515113254/Atlas_da_Politica_Brasileira_de_Defesa. pdf> Acesso em: 16 jul. 2019.

LINDSTROM, Gustav. Enter the EU Battlegroups. Institute for Security Studies, Paris, n. 97,p.590, Feb. 2007. Available at: <https://www.iss.europa.eu/sites/default/files/EUISSFiles/cp097.pdf> Acesso em: 03 jan. 2018.

LUSTY, Paul A; MURTON, Bramley J.Deep-Ocean Mineral Deposits:Metal Resources and Windowsinto Earth Processes. Elements, UK, v.14, n.5, p. 301-306, Oct 2018. Available at: <DOI: 10.2138/gselements.14.5.301>Acesso em: 16 jul. 2019.

MACLAY et al. The Fourth Fleet: A Tool of U.S. Engagement in the Americas. Washington: Center for Strategic e International Studies, Feb. 2009. Available at: <http://www.voltairenet.org/IMG/pdf/The_Fourth_Fleet.pdf> Acesso em: 19 dez. 2017.

MADEIRA, Joao Paulo; MONTEIRO, Nataniel Andrade. Cabo Verde: Entre as Estratégias de Segurança EuroAtlântica e a Nova Dimensão de Parceria Sul-Sul=Cape Verde: Betweenthe Euro-Atlantic Security Strategysandthe New Dimension of South-South Partnership. Meridiano 47 Journal of Global Studies, $\quad[$ S.1], $\quad$ v. $\quad 17, \quad$ p.1-11, 2016. Available at: <http://periodicos.unb.br/index.php/MED/article/view/M47e17011>. Acesso em: 03 jan. 2018.

MARTINS, L.R; BARBOZA, E.G; ROSA, M.L.C.C. Nódulos Polimetálicos e outros Depósitos de Mar Profundo: o Retorno do Interesse. Centro de Estudos de Geologia e Oceânica, Porto Alegre, n. 4, p.125131, 2006. Available at: <http://www.ufrgs.br/gravel/4/Gravel_4_11.pdf>Acessoem: 31 out. 2017.

MEARSHEIMER, John J. The False Promise of Liberal Hegemony. 22 Nov. 2017. Disponível em <https://www.youtube.com/watch?v=ESwIVY2oimI> Acesso em: 22 Set. 2018.

MERKE, Federico. Political and Military Utility of NATO for Argentina. In EDSTRÖM, Håkan; MATLARY, Janne; PETERSSON, Magnus (eds). NATO: The Power of Partnerships. New York: Palgrave Macmillan, 2011, p.181-208.

MESFIN, Berouk. The establishment and implications of the United States Africa Command: An African perspective. Institute for Security Studies, n. 183, Apr. 2009. Available at: <https://www.files.ethz.ch/isn/99270/PAPER183.pdf>. Acesso em: 19 dez. 2017. .

MODERN GHANA. Gaf-Nato military exercises ends. 21 Oct. 2005. Disponível em <https://www.modernghana.com/news/88571/gaf-nato-military-exercises-ends.html> Acesso em 11 Jan. 2018.

NEVES, Miguel Santos. A China e a Îndia no Atlântico Sul. Relações Internacionais, Lisboa, n. 38, p. 71-94, jun. 2013. Available at: <http://www.scielo.mec.pt/scielo.php?script=sci_arttext\&pid=S164591992013000200007>. Acesso em: 30 set. 2017.

NATO (North Atlantic Treaty Organization). Mauritania. Science For Peace and Security Programme, Jul. 2017. Disponível em <http://www.nato.int/science/country-fliers/Mauritania-ENG.pdf> Acesso em: 20 Nov. 2017.

NATO. The Alliance's New Strategic Concept. 1991. Available at: <http://www.nato.int/cps/en/natohq/official_texts_23847.htm>. Acessoem: 18 jun. 2017. 
NATO. The Alliance's Strategic Concept. Nov. 2010. Available at: <https://www.nato.int/cps/ic/natohq/topics_82705.htm>. Acesso em: 18 jun. 2017.

ONUOHA, Freedom C.; EZIRIM, Gerald E. "Terrorism" and Transnational Organised Crime in West Africa. Al Jazeera Centre for Studies, Mecca, 24 June 2013. Available at: <http://studies.aljazeera.net/en/reports/2013/06/2013624102946689517.html>. Acesso em: 15 nov. 2017.

ORFY, Mohammed M. NATO's role in the Middle East before 9/11. In: Nato and the Middle East: The geopolitical context post-9/11. London: New York: Routledge Studies in Middle Eastern Politics, 2011, p. 91- 108.

PENHA, Eli Alves. Relações Brasil-África e Geopolítica do atlântico Sul. Salvador: EDUFBA, 2011, 245p.

PENHA, Eli Alves. A Segurança e a Defesa doAtlântico Sul no Âmbito daCooperação Brasil-África: Vontade e Capacidade de Soberania. Ministério da Defesa, XIII Curso de Extensão em Defesa Nacional, maio 2016. Available

at: <https://www.defesa.gov.br/arquivos/ensino_e_pesquisa/defesa_academia/cedn/XIII_cedn/a_segur anca_e_a_defesa_do_atlantico_sul_no_ambito_da_cooperacao_brasil-africa.pdf> Acesso em: 17 jul. 2019.

PEREIRA, Letícia. Colômbia: As FARC e os Diálogos de Paz. Série Conflitos Internacionais, v. 2, n. 1, fev. 2015. Available at: <https://www.marilia.unesp.br/Home/Extensao/observatoriodeconflitosinternacionais/farc-eosdialogos-de-paz.pdf>Acesso em: 30 nov. 2017. .

PICHON, Eric; PIETSCH, Marian. Piracy andarmed robberyoff the coast ofAfrica: EU and globalimpact. European Parliamentary Research Service, Brussels, March 2019. Available at: <http://www.europarl.europa.eu/RegData/etudes/IDAN/2019/635590/EPRS_IDA(2019)635590_EN. pdf> Acesso em: 16 jul. 2019.

PINO, Manuel de Jesús Rocha. China y laintegraciónmegarregional: la Nueva Ruta de la Seda Marítima en África=China andmegaregionalintegration: the New MaritimeSilk Road in Africa. CIDOB Barcelona Center for International Affairs, n. 114, p. 87-108, 2016. Available at: $<$ https://www.cidob.org/articulos/revista_cidob_d_afers_internacionals/114/china_y_la_integr acion_megarregional_la_nueva_ruta_de_la_seda_maritima_en_africa $>$. Acesso em: 03 ago. 2017.

PORTS AND SHIPS. SA sub causes red faces in Nato exercise. 6 Sept, 2007. Available at: <http://ports.co.za/navalnews/article_2008_01_19_1038.html>Acesso em: 12 jan. 2018.

PORTUGAL. Instituto de Defesa Nacional. Conceito Estratégico de Defesa Nacional 2013. 2013. Available at: <http://www.idn.gov.pt/conteudos/documentos/CEDN_2013.pdf> Acesso em: 22 dez. 2017.

PRYCE, Paul. The Incongruence of IBSAMAR. ETH Zurich Center for Security Studies. Nov. 2014. Available at: <http://www.css.ethz.ch/en/services/digitallibrary/articles/article.html/185327/>. Acesso em: 07 dez. 2017.

RATTI, Luca. Post-cold war Nato and international relations theory: The case for neoclassical realism. Journal of Transatlantic Studies, v.4, n.1, p.81-110, 2006. Disponívelem<https://www.tandfonline.com/doi/ref/10.1080/14794010608656841?scroll=top>Ace sso em: 03 Nov. 2018.

RAY, Rebecca; GALLAGHER, Kevin P. China-Latin America Economic Bulletin 2017 Edition. Global Economic Governance Initiative, Boston, 2017. Available at: <https://www.bu.edu/pardeeschool/files/2014/11/Economic-Bulletin.1617Bulletin.Draft_.pdf $>$ Acesso em: 30 set. 2017. 
REFICCO, Ezequiel. Argentina como aliado extra-OTAN de los EE UU: losfactores detrás de laalianza. Revista CIDOB d' Afers Internacionals, [S.1], n. 42, 1998. Available at: <http://www.raco.cat/index.php/RevistaCIDOB/article/view/28094> Acesso em: 15 dez. 2017.

RINGSMOSE, Jens; RYNNING, Sten. Introduction. Taking Stock of NATO’s New Strategic Concept. In: (Ed.). Nato's New Strategic Concept: A Comprehensive Assessment. Danish Institute For International Studies. $\quad$ Copenhagen, $2011 . \quad$ Available at: <https://www.files.ethz.ch/isn/128345/RP2011-02-NATO_web.pdf>. Acesso em: 10 jun. 2017.

SANCHEZ, Alex W. Geopolitical Considerations of the NATO-Colombia Cooperation Agreement. Mar. 2014. In: Center for Security Studies: ETH Zurich. Available at: $<$ http://isnblog.ethz.ch/security/geopolitical-considerations-of-the-nato-colombiacooperationagreement>. Acesso em: 12 out. 2017.

SANTORA, Mark. Trump Derides NATO as 'Obsolete.' Baltic Nations See It Much Differently. The New York Times. July 10, $2018 . \quad$ Available at: <https://www.nytimes.com/2018/07/10/world/europe/trump-nato-summit-latvia-baltics.html>

SEABRA, Pedro. A case of unmet expectations: Portugal and the South Atlantic. Portuguese Journal of Social Science, [S.l], v. 13, n. 3, p. 331-346, 2014. Available at: <https://kuldoc.com/download/acase-of-unmet-expectations-portugal-and-the-south-atlanticportuguese-journal-of-socialscience-2014-_59c52d671723dda0bd20ccbd_pdf>. Acesso em: $22 \mathrm{dez} .2017$.

SERRONHA, Marco. Portugal e o novo Conceito Estratégico da nato. Relações Internacionais, Lisboa, n. 27, p.55-64, set. $2010 . \quad$ Available at: <http://www.scielo.mec.pt/scielo.php?script=sci_arttext\&pid=S1645-91992010000300006> Acesso em: 23 dez. 2017.

SILVA; Antonio Ruy de Almeida. O Atlântico Sul na Perspectiva da Segurança e da Defesa. In: NASSER, Reginaldo Mattar; MORAES, Rodrigo Fracalossi de. (Org.). Brasil e a segurança no seu entorno estratégico: América do Sul e Atlântico Sul. Brasília: Instituto de Pesquisa Econômica Aplicada, 2014, p.199-213. Available at: $<$ http://ipea.gov.br/portal/index.php?option=com_content\&view=article\&id=21592>. Acesso em: 13 dez. 2017.

SIRECI, Jonathan; COLETTA, Damon. Enduring without an Enemy: NATO's Realist Foundation. Perspectives, v.17, n.1 p.57-81, 2009. Availableat: <http://www.jstor.org/stable/23616104> Acesso em 13 Nov. 2018.

SOLLER, Diana. O Relatório Albright e a Grande Estratégia Obama: um caso de convergência? Relações Internacionais, Lisboa, n. 27, p.09-21, 2010. Disponível em <http://www.scielo.mec.pt/scielo.php?pid=S1645-91992010000300002 \&script=sci_abstract > Acesso em 29 dez. 2017.

SULLIVAN, Eileen. Trump Questions the Core of NATO: Mutual Defense, Including Montenegro. The New York Times. July 18, 2018. Available at <https://www.nytimes.com/2018/07/18/world/europe/trump-nato-self-defense-montenegro.html>

TASE, Peter. LATIN AMERICA: NATO Interested in Colombia. Global Perspectives, 2014. Available at: <http://www.global-perspectives.info/index.php/internationaledition/2014/quarterly-one/417latin-america-nato-interested-in-colombia>. Acesso em: 12 out. 2017.

UNITED KINGDOM. Ministry of Defence. Overseas Territories: the Ministry of Defence's contribution. 2012. 
USA (United States of America). The National Security Strategy. March 2006. Available at: <https://www.state.gov/documents/organization/64884.pdf>. Acesso em: 29 dez. 2017.

VARELA, Odair B. B. L. A Encruzilhada da Defesa e Segurança no Atlântico Médio: Cabo Verde entre a «Espada» da NATO e a «Parede» Africana?. Revista Direito e Cidadania, Ano VII, n. 25-26, 2007. Availableat: <http://www.portaldoconhecimento.gov.cv/handle/10961/3271> Acesso em: 03 jan. 2018.

VIEGAS FILHO, José. A Segurança do Atlântico Sul e as relações com a África. Brasília: Fundação Alexandre de Gusmão, 2016. Available at: <http://funag.gov.br/loja/download/1180-a-segurancado-atlantico-sul-e-as-relacoes-com-aafrica.pdf>. Acesso em: 25 abr. 2017.

WALTZ, Kenneth. Structural Realism after the Cold War. International Security, [S.1], v. 25, n. 1, p. 5-41, 2000.

WILTGEN, Guilherme. O Brasil e seu "mar interior". Defesa Aérea e Naval. 26 dez. 2013. Available at: <http://www.defesaaereanaval.com.br/o-brasil-e-seu-mar-interior/>Acessoem: $21 \mathrm{dez} .2017$.

YOST, David S. NATO's evolving purposes and the next Strategic Concept. International Affairs, v. 86, n. 2, p. 489-522, Mar. 2010. Available at: <http://onlinelibrary.wiley.com/doi/10.1111/j.14682346.2010.00893.x/abstract>Acessoem: 10 jun. 2017. 


\begin{abstract}
This article contributes to the studies on NATO out-of-area operations focused on the South Atlantic. This region appeared on the organization's agenda for the first time in the 1970s, when the Soviet presence threatened the commercial maritime transport of the Western powers. After the Cold War, the Alliance has transformed its capabilities and structure in order to adapt to the events of the new international security arena by expanding its activities beyond the North Atlantic borders. Partnership agreements with Colombia and Mauritania, joint military exercises with Cape Verde, Ghana and other West African countries evidence NATO projection in the South Atlantic. In addition, the article exposes the abundance of natural resources, threats to security and the growing projection of extraregional actors (Russia, China and India) as likely factors for NATO engagement in the region.
\end{abstract}

Key-words:NATO, out-of-area operations, South Atlantic.

\title{
RESUMO
}

Este artigo contribui para os estudos sobre operações out-of-area da OTAN focado no Atlântico Sul. Pela primeira vez, essa região apareceu na agenda da organização na década de 1970, quando a presença soviética ameaçou o transporte marítimo comercial das potências ocidentais. Após a Guerra Fria, a Aliança transformou suas capacidades e estrutura para adaptar-se aos eventos do novo cenário de segurança internacional, expandindo atividades além das fronteiras do Atlântico Norte. Acordos de parceria com a Colômbia e Mauritânia, exercícios militares conjuntos com Cabo Verde, Gana e outros países da África Ocidental evidenciam a projeção da OTAN no Atlântico Sul. Além disso, o artigo expõe a abundância de recursos naturais, as ameaças à segurança e a crescente projeção de atores extrarregionais (Rússia, China e Índia) como prováveis fatores de engajamento da OTAN na região.

Palavras-chave: OTAN, Operações out-of-area, Atlântico Sul.

\section{COPYRIGHT:}

Este é um artigo publicado em acesso aberto e distribuído sob os termos da Licença de Atribuição Creative Commons, que permite uso irrestrito, distribuição e reprodução em qualquer meio, desde que o autor e a fonte originais sejam creditados.

This is an open-access article distributed under the terms of a Creative Commons Attribution License, which permits unrestricted use, distribution, and reproduction in any medium, provided that the original author and source are credited.

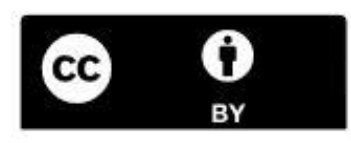

